Article

\title{
Installation and Operation of a Solar Cooling and Heating System Incorporated with Air-Source Heat Pumps
}

\author{
Li Huang ${ }^{1, *}$, Rongyue Zheng ${ }^{1}$ and Udo Piontek ${ }^{2}$ \\ 1 Faculty of Architecture, Civil Engineering College, Ningbo University, Fenghua Street 818, \\ Ningbo 315211, China; rongyue@nbu.edu.cn \\ 2 Fraunhofer Institute for Environmental, Safety, and Energy Technology UMSICHT, Osterfelder Strasse 3, \\ 46047 Oberhausen, Germany; udo.piontek@umsicht.fraunhofer.de \\ * Correspondence: huangli@nbu.edu.cn; Tel.: +86-574-8760-9510
}

Received: 21 January 2019; Accepted: 11 March 2019; Published: 14 March 2019

\begin{abstract}
A solar cooling and heating system incorporated with two air-source heat pumps was installed in Ningbo City, China and has been operating since 2018. It is composed of 40 evacuated tube modules with a total aperture area of $120 \mathrm{~m}^{2}$, a single-stage and LiBr-water-based absorption chiller with a cooling capacity of $35 \mathrm{~kW}$, a cooling tower, a hot water storage tank, a buffer tank, and two air-source heat pumps, each with a rated cooling capacity of $23.8 \mathrm{~kW}$ and heating capacity of $33 \mathrm{~kW}$ as the auxiliary system. This paper presents the operational results and performance evaluation of the system during the summer cooling and winter heatingperiod, as well as on a typical summer day in 2018. It was found that the collector field yield and cooling energy yield increased by more than $40 \%$ when the solar cooling and heating system is incorporated with heat pumps. The annual average collector efficiency was $44 \%$ for cooling and $42 \%$ for heating, and the average coefficient of performance (COP) of the absorption chiller ranged between 0.68 and 0.76 . The annual average solar fraction reached $56.6 \%$ for cooling and $62.5 \%$ for heating respectively. The yearly electricity savings accounted for $41.1 \%$ of the total electricity consumption for building cooling and heating.
\end{abstract}

Keywords: solar cooling; solar heating; heat pump; absorption chiller; evacuated tube collector

\section{Introduction}

In recent years, building energy consumption has been steadily increasing with the development of the economy and the improvement of living standards in China. It occupies $30 \%$ of the total energy consumption in China [1], 50-60\% of which is consumed by air conditioning in public buildings in hot summer and cold winter zones [2]. Conventional air conditioning systems use electricity to drive a compressor to circulate a refrigerant which absorbs and removes heat from the space. The rising air conditioner usage not only results in a considerable increase in power consumption, but also in a power peak demand during the hottest hours in summer, which has a strong negative impact on the existent power grid and often causes power blackouts in summer.

Solar cooling technology has been developed to reduce the increasing electricity consumption for air conditioning and to shift the peak load on hot summer days. This technology uses solar energy to drive a refrigerator to cool the space and reduces the electricity consumption. Many researchers have focused on solar cooling systems and different types have been investigated. As of 2014, about 1200 solar cooling systems have been installed worldwide, most of them in Europe [3]. It is considered that about $71 \%$ of the installations are solar absorption cooling systems, and $13 \%$ are adsorption systems. Some of the installed systems have been studied in the literature, both in terms of thermodynamic and economic performance. For example, Syed et al. [4] tested a flat-plate collector-driven $35 \mathrm{~kW}$ 
single-effect $\mathrm{LiBr}$-water absorption chiller in Madrid. The maximum instantaneous coefficient of performance (COP) (COP is the ratio of cooling energy yield and heat supplied by the generator), daily average COP and average COP during the period of 20 days of monitoring (25/07/2003 to 19/08/2003) were $0.60,0.42$, and 0.34 , respectively. Pongtornkulpanich et al. [5] tested a 10-ton single effect $\mathrm{LiBr}$-water absorption chiller powered by an evacuated tube solar collector in Thailand where the solar collector delivered $81 \%$ of the thermal energy for the chiller. Rosiek and Batlles [6] analyzed the behavior of the solar-assisted air-conditioning system installed in the CIESOL building to maximize the use of solar thermal energy supplying the cooling and heating system. The average values of coefficient of performance and the cooling capacity in summer months were 0.6 and $40 \mathrm{~kW}$, respectively. Bermejo et al. [7] built and tested a solar/gas-driven double effect LiBr-water absorption system in Spain. The system could be driven by a direct-fired natural gas burner or by pressurized hot water delivered from a linear concentrating Fresnel collector. The average and maximum daily efficiencies of the solar collector were 0.35 and 0.4 , respectively. The daily average COP of the chiller was 1.1-1.25. Lizarte et al. [8] experimentally studied a vacuum flat-plate collector-driven $4.5 \mathrm{~kW}$ air-cooled single-effect LiBr-water absorption chiller in Madrid. It was found that the mean COP and solar coefficient of performance (SCOP) (the ratio of cooling energy yield and the total solar energy available) were 0.53 and 0.06 , respectively. Balghouthi et al. [9] presented a solar absorption cooling installation in Tunisia where it was found that the coefficient of performance (COP) ranged between 0.8 and 0.91 during the installation running, while the solar coefficient of performance (SCOP) was between 0.1 and 0.43 . The drain backup night storage improved the average solar fraction (SF) of the system, which increased from 0.54 to 0.77 .

Hang et al. [10] built a double-effect solar absorption cooling test facility and investigated the experimentally based energy performance of the system. The results showed that the system could provide adequate cooling for a test facility between 11 a.m. and 5 p.m. on both sunny and cloudy days. The daily average collector efficiency was in the range of $36 \%$ to $39 \%$. The average coefficient of performance (COP) of the LiBr-water absorption chiller was between 0.91 and 1.02 with an average of 1.0, and the daily solar COP was approximately at 0.374 . Marc et al. [11] presented a dynamic modeling of a single-effect absorption chiller working with a LiBr-water solution used in a solar cooling installation operating without any backup systems (hot or cold). The numerical model was based on the mass and energy balances of each component, equations of state, and equations of heat transfers. Experimental validation elements were proposed to validate pressures and temperatures of the chiller. $\mathrm{Xu}$ et al. [12] studied a variable effect $\mathrm{LiBr}-$ water absorption chiller based upon a real developed $50 \mathrm{~kW}$ prototype. The results showed that the COP increased from 0.69 to 1.08 under generation temperature from $95^{\circ} \mathrm{C}$ to $120^{\circ} \mathrm{C}$. The chiller performance will be higher under high chilled water temperature, low cooling water temperature, proper frequency of generation pump, optimized high pressure absorber valve opening, and high frequency of hot water pump.

Since the first solar cooling system was installed in Shenzhen in 1987, there have been over 10 demonstration projects put into service in China. The first system in Shenzhen provided cooling in summer to guestrooms with a total area of $80 \mathrm{~m}^{2}$ by applying two single-stage LiBr-water absorption chillers and a hot water boiler as the auxiliary heat source. It was found that the $\mathrm{LiBr}$-water absorption chiller could not always operate at its nominal rating during periods of low solar radiation and high cooling water temperature as the temperature in the storage could not always be maintained at temperatures as high as $88-90^{\circ} \mathrm{C}$ throughout the day even on clear sunny days [13]. Two of the most famous solar absorption cooling systems of Tianpu and Beiyuan were built in Beijing in 2001 and 2005, respectively. The Tianpu demonstration project consists of a $200 \mathrm{~kW}$ solar absorption cooling system assisted by a ground-source heat pump with a rated cooling capacity of $391 \mathrm{~kW}$. It was reported that the average solar collecting efficiency in summer exceeded $40 \%$ [14]. So far, the largest solar cooling system in China is the demonstration project of Beiyuan. A single-effect $\mathrm{LiBr}$-water absorption chiller was chosen to supply cooling to the building with an area of $3000 \mathrm{~m}^{2}$. An electric boiler was installed as an auxiliary heat source. When the ambient temperature was about $30.3^{\circ} \mathrm{C}$ during the experimental 
period, the average solar collecting efficiency and the COP of the chiller was 0.42 and 0.75 , respectively, whereas the average indoor air temperature was $23.8^{\circ} \mathrm{C}$ [15].

Due to the intermittent nature of solar energy, a backup system is required in solar cooling and heating systems to meet the building load demand when solar inputs are insufficient. The backup system can use either gas or electricity as the auxiliary energy source [16]. Most of the above-mentioned solar cooling and heating systems used a gas boiler as an auxiliary heat source. In this paper, a new system incorporated with two air-source heat pumps as the auxiliary system was installed in Ningbo City, which is located in the hot summer and cold winter zone in China, and it has been operating since 2018. This paper presents the installation and performance evaluation of the solar cooling and heating system during the summer cooling and winter heating period, as well as on a typical summer day, namely, 23 July 2018.

\section{Climate Conditions and Building Characteristics}

\subsection{Climate Conditions}

Figure 1 presents the monthly average outdoor temperature and global solar irradiation in Ningbo City in 2018. The average outdoor temperature during July, the hottest month, is $27.6^{\circ} \mathrm{C}$, whereas the average outdoor temperature during January, the coldest month, is $6^{\circ} \mathrm{C}$. Thus, air conditioning systems are necessary for both cooling in summer and heating in winter. The average sunshine hours are $1855.6 \mathrm{~h}$ per year and the average daily sunshine hours are $5.41 \mathrm{~h}$. The total annual solar radiation is $1280.5 \mathrm{kWh} / \mathrm{m}^{2}$, which is $78 \%$ of the average value of $1627.8 \mathrm{kWh} / \mathrm{m}^{2}$ in China.

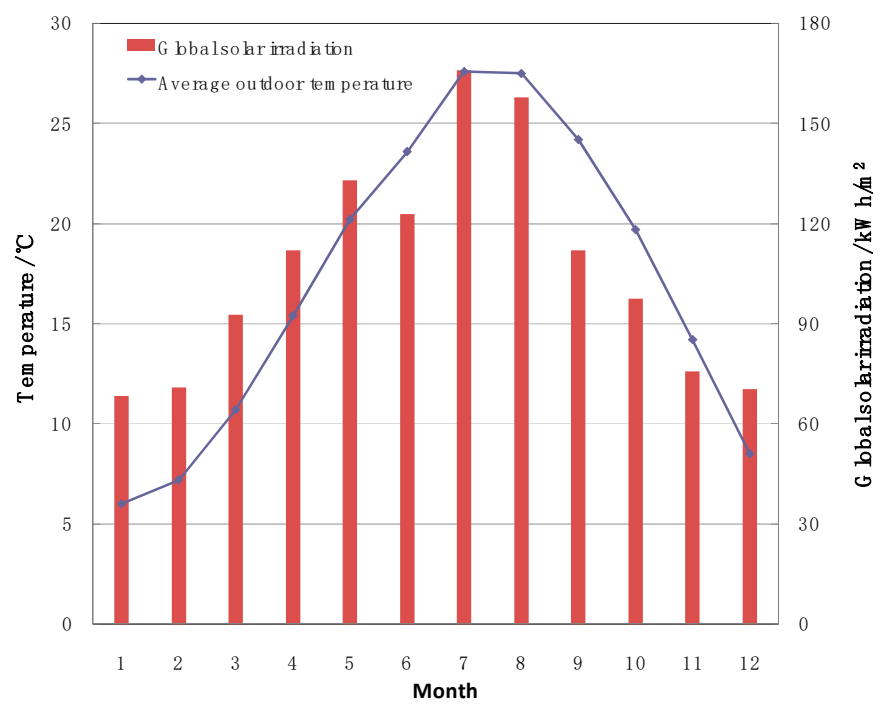

Figure 1. The monthly average outdoor temperature and global solar irradiation in Ningbo in 2018.

Figure 2 shows the hourly average outdoor temperature and global solar irradiation on 23 July 2018. The strongest solar radiation occurred from 9:00 to 13:00, while the temperatures exceeded $32{ }^{\circ} \mathrm{C}$ between 11:00 and 14:00, which also corresponded to the maximal cooling energy demand during the day.

\subsection{Building Characteristics}

The building, which the solar cooling system serves, is an office building of a tourist center as shown in Figure 3 and occupied for $10 \mathrm{~h}$ from 8:00 to 18:00 every day. The two-story building has a total area of $242.4 \mathrm{~m}^{2}$ and a total height of $6.9 \mathrm{~m}$. The specific cooling and heating power demands are $120 \mathrm{~W} / \mathrm{m}^{2}$ and $82 \mathrm{~W} / \mathrm{m}^{2}$, respectively, and the total cooling and heating loads are $29 \mathrm{~kW}$ and $20 \mathrm{~kW}$, 
respectively. There is no hot water demand in the building. The construction characteristics of this building are shown in Table 1.

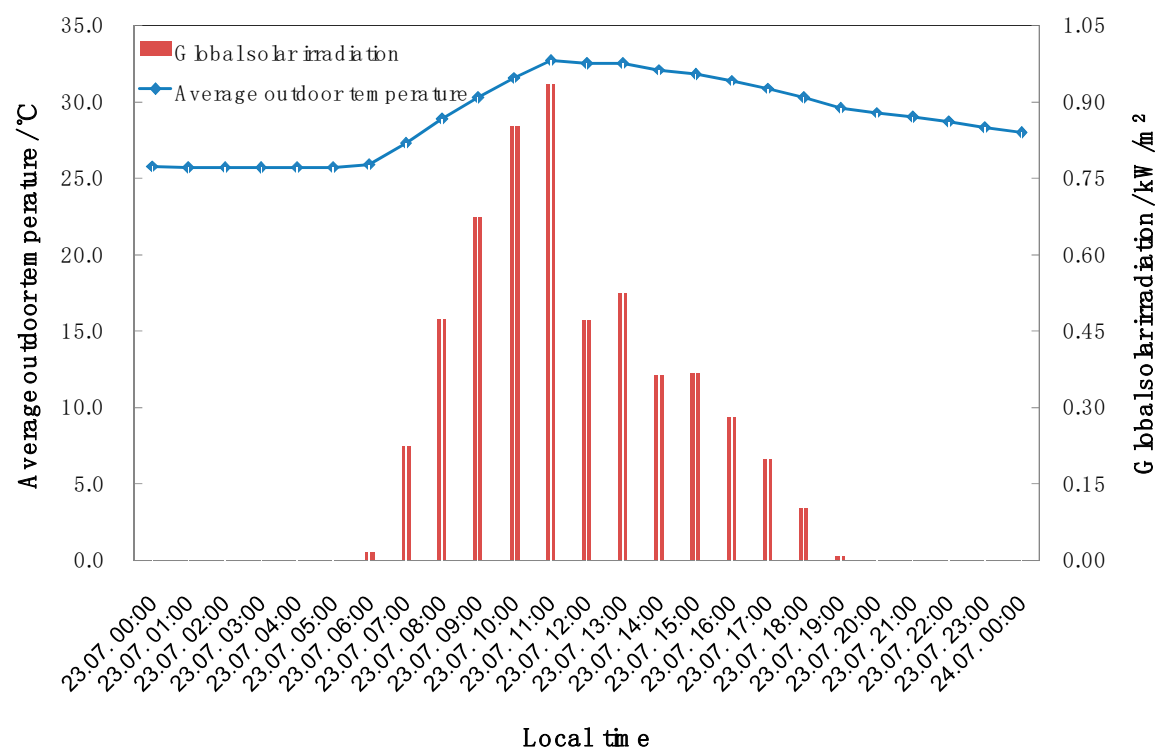

Figure 2. The hourly average outdoor temperature and global solar irradiation on 23 July 2018.

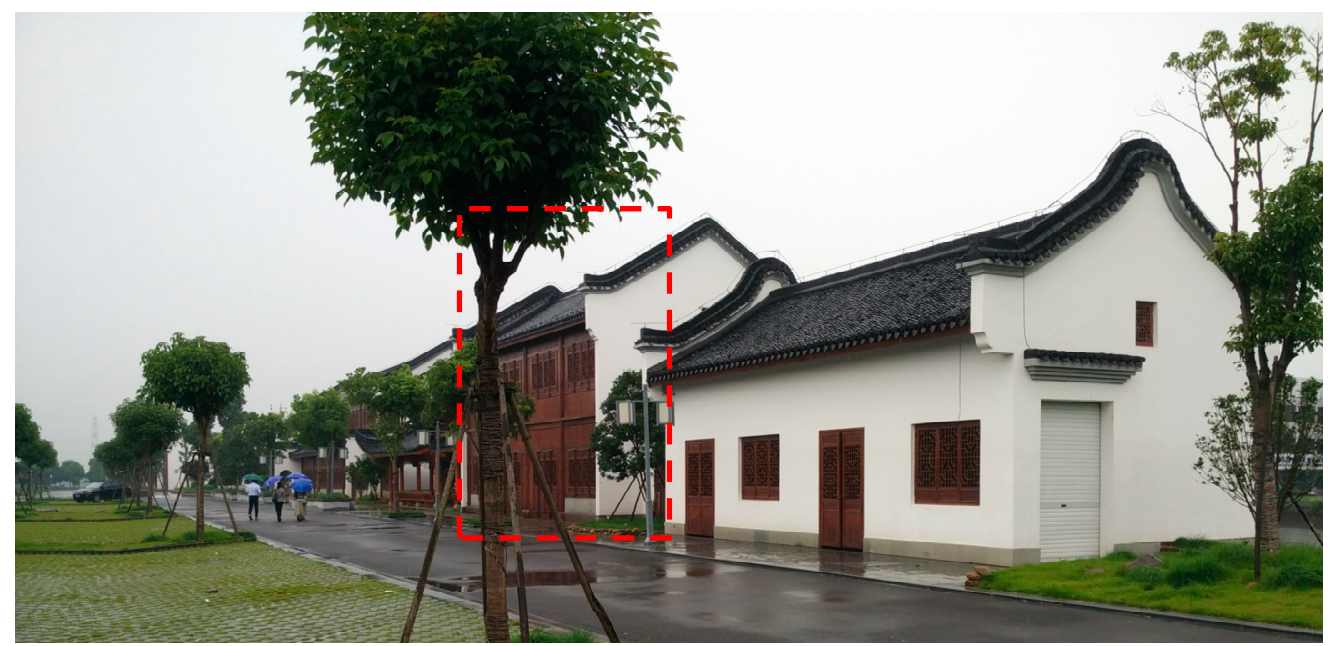

Figure 3. The tourist center and the office building marked with the red frame, which the solar cooling system serves.

Table 1. The construction characteristics of the building.

\begin{tabular}{ccc}
\hline Parameter & & Value \\
\hline Total U-value $\left(\mathrm{W} / \mathrm{m}^{2} \cdot \mathrm{K}\right)$ & & 0.5 \\
& North & 13 \\
Window-to-wall area ratio $(\%)$ & West & 6 \\
& East & 25 \\
& South & 25 \\
Type of window & Frame & PVC-U \\
U-window $\left(\mathrm{W} / \mathrm{m}^{2} \cdot \mathrm{K}\right)$ & Glass & Double clear $(5 / 9 / 5)$ \\
g-value window ${ }^{*}(-)$ & & 3.0 \\
Air change $(1 / \mathrm{h})$ & & 0.8 \\
\hline
\end{tabular}

* g-value window: solar heat gain coefficient of window. 


\section{System Installation}

The installation is a solar collector-based thermal cooling system where a LiBr-water absorption chiller is driven by hot water from the solar collectors. As shown in Figure 4, it consists of two arrays of evacuated tube collectors, an air-cooled radiator to prevent overheating of the solar collectors, an absorption chiller, a cooling tower, a hot water storage tank, a buffer tank, and two air-source heat pumps as an auxiliary system. During the summer cooling time, the solar collector field transfers solar radiation into thermal energy to produce hot water at a temperature range of $70-110{ }^{\circ} \mathrm{C}$, which is stored in the hot water storage tank. The absorption chiller is driven by the hot water and produces chilled water at a temperature of $10-15{ }^{\circ} \mathrm{C}$, which is stored in the buffer tank for building cooling. The cooling tower is used to extract waste heat from the chiller. The heat pumps additionally provide chilled water when solar energy is insufficient. During the winter heating time, the absorption chiller is switched off, and the hot water with a temperature range between $45^{\circ} \mathrm{C}$ and $60^{\circ} \mathrm{C}$ produced by the solar collector field is directly used for building heating. The heat pumps additionally provide hot water when solar energy is insufficient.

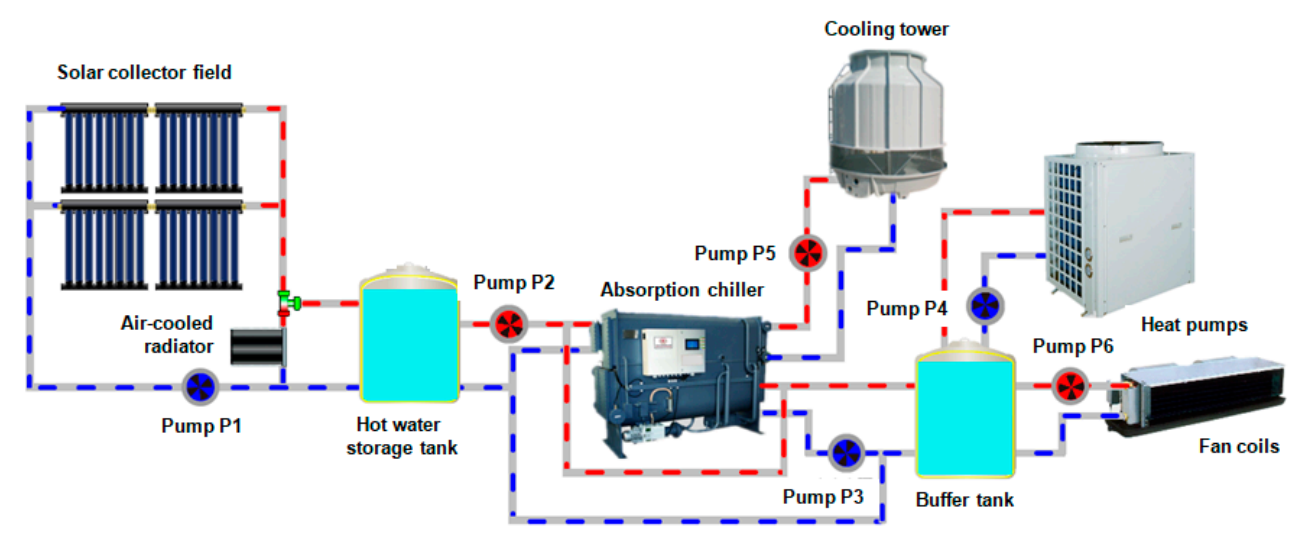

Figure 4. The schematic of the solar thermal cooling and heating system.

\subsection{Description of the System Components}

\subsubsection{The Solar Collector Field}

The main heat driving source of the installation is the solar collector field, which was installed on the roof of a steel-structure parking shed near the office building shown in Figure 5 (left). It comprises 40 all-glass evacuated tube modules in two parallel arrays with a total aperture area of $120 \mathrm{~m}^{2}$. Each module contains 18 evacuated tubes and has an aperture area of $3.0 \mathrm{~m}^{2}$.

\subsubsection{The Absorption Chiller}

The absorption chiller presented in Figure 5 (right) is a single-stage and LiBr-water based machine associated with a cooling tower shown in Figure 6 (left). This chiller had a cooling capacity of $35 \mathrm{~kW}$. The hot water design inlet and outlet temperatures were $80^{\circ} \mathrm{C}$ and $75{ }^{\circ} \mathrm{C}$, respectively, and the rated flow was $8.6 \mathrm{~m}^{3} / \mathrm{h}$; the chilled water design inlet and outlet temperatures were $15{ }^{\circ} \mathrm{C}$ and $10{ }^{\circ} \mathrm{C}$ respectively, and the rated flow was $6.0 \mathrm{~m}^{3} / \mathrm{h}$; the cooling water design inlet and outlet temperatures were $30^{\circ} \mathrm{C}$ and $35^{\circ} \mathrm{C}$, respectively, and the rated flow was $15.0 \mathrm{~m}^{3} / \mathrm{h}$. The cooling tower had a rated water flow of $25.0 \mathrm{~m}^{3} / \mathrm{h}$. 

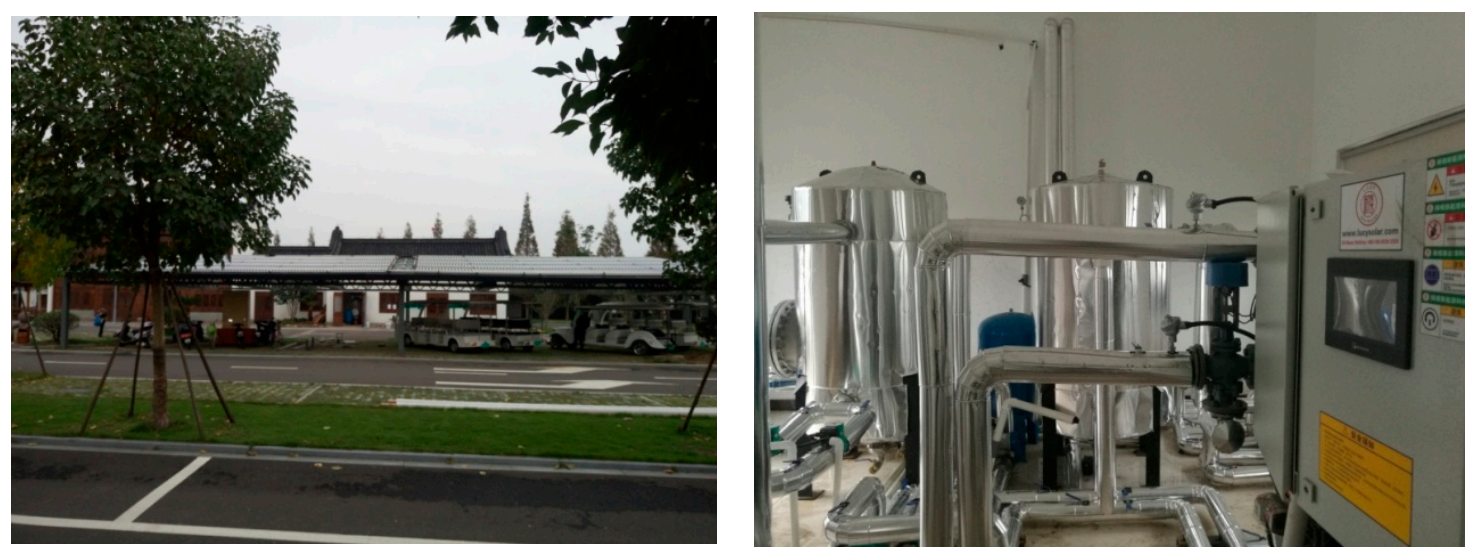

Figure 5. Photos of the (left) solar collector field on the roof of a steel-structure parking shed and the (right) equipment room.
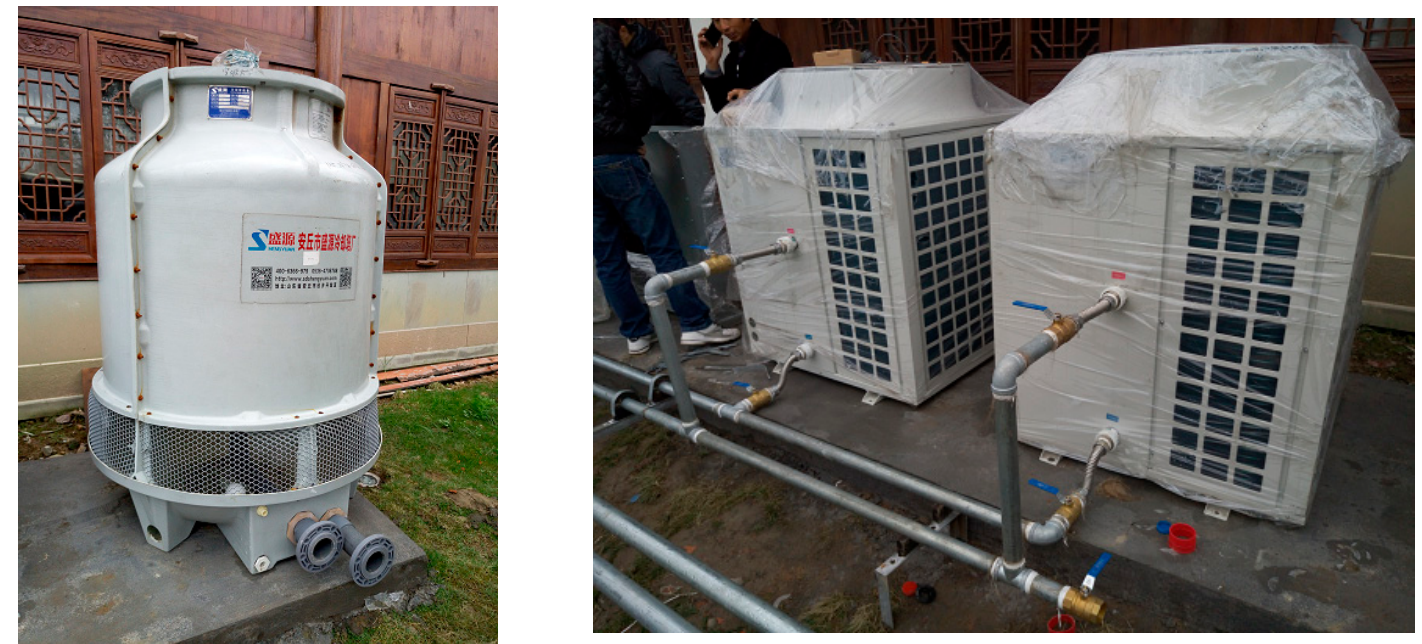

Figure 6. Photos of the (left) cooling tower and the (right) two heat pumps.

\subsubsection{The Thermal Energy Storage}

In order to make rational use of solar energy and to maximize the energy efficiency, two pressure storage tanks were used in the installation, which were a hot water storage tank with a volume of $4 \mathrm{~m}^{3}$ and a buffer tank with a volume of $1 \mathrm{~m}^{3}$. The hot water storage tank had built-in heat exchanger coils and the heat transfer capacity was $58 \mathrm{~kW}$.

\subsubsection{The Auxiliary System}

An auxiliary system is required due to the instability of solar energy. Two air-source heat pumps were applied in the installation as shown in Figure 6 (right). The rated cooling capacity was $23.8 \mathrm{~kW}$ and the heating capacity was $32 \mathrm{~kW}$.

\subsection{Description of the Controlling and Monitoring System}

The controlling and monitoring system is very important for the safe and stable running of this installation. As presented in Figure 7, the solar radiation $I_{\text {solar }}$, the temperatures $T_{0}-T_{17}$, the mass flow rates $F_{1}-F_{4}$, and the electrical consumption $E_{1}$ were recorded by the monitoring system. Table 2 presents the instruments and their calibration range and uncertainty. 


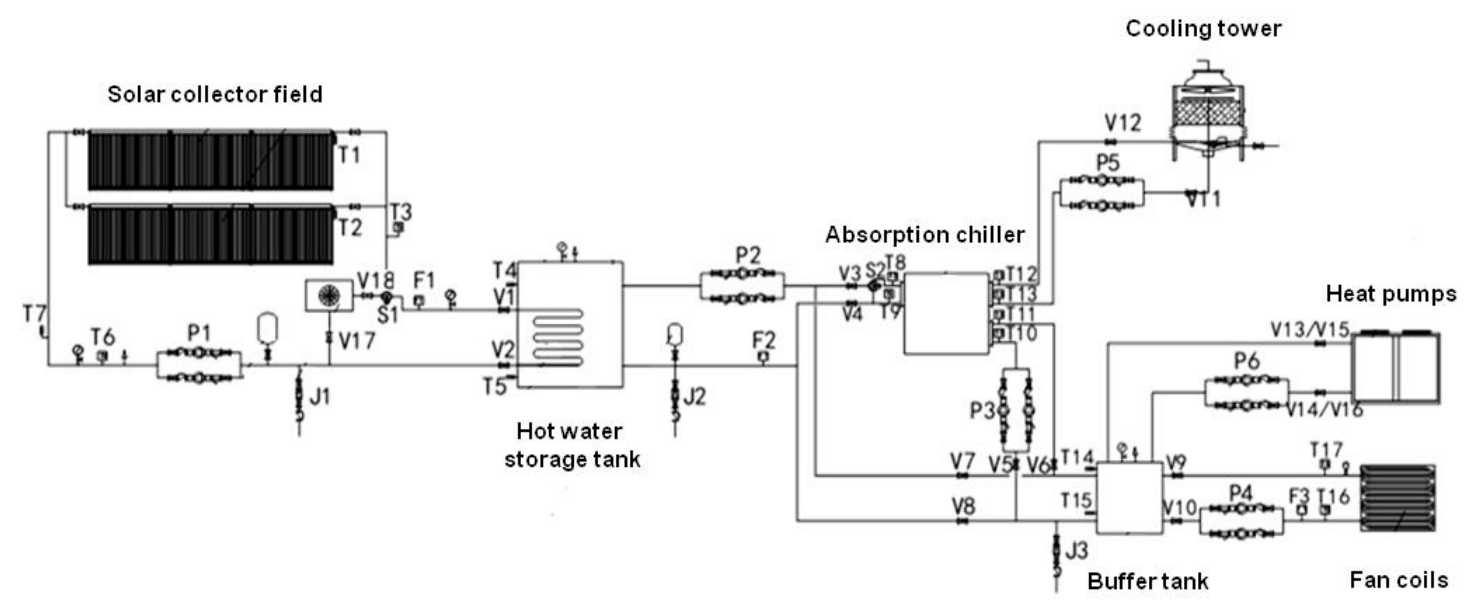

Figure 7. The schematic of the controlling and monitoring system: $T_{0}$ - the ambient temperature; $T_{1}$-the temperature of the collector array $1 ; T_{2}$-the temperature of the collector array $2 ; T_{3}$ - the outlet temperature of the collector field; $T_{4}$-the upper layer temperature of the hot water storage tank; $T_{5}$ - the lower layer temperature of the hot water storage tank; $T_{6}$ - the inlet temperature of the collector field; $T_{7}$-the antifreeze temperature of the collector field; $T_{8}$ - the hot water inlet temperature of the absorption chiller; $T_{9}$ - the hot water outlet temperature of the absorption chiller; $T_{10}$ - the chilled water outlet temperature of the absorption chiller; $T_{11}$-the chilled water inlet temperature of the absorption chiller; $T_{12}$ - the cooling water outlet temperature of the absorption chiller; $T_{13}$ - the cooling water inlet temperature of the absorption chiller; $T_{14}$-the upper layer temperature of the buffer tank; $T_{15}$ - the lower layer temperature of the buffer tank; $T_{16}$-the inlet temperature of the fan coils; $T_{17}$-the outlet temperature of the fan coils; $I_{\text {solar }}$-solar radiation; $F_{1}$ - the inlet flow rate of the collector field; $F_{2}$ - the hot water inlet flow rate of the absorption chiller; $F_{3}$ - the chilled water inlet flow rate of the absorption chiller; $F_{4}$-the inlet flow rate of the fan coils; $E_{1}$-the electrical consumption of the heat pumps.

Table 2. The instruments and their calibration range and uncertainty.

\begin{tabular}{cccc}
\hline Parameter & Instrument & Calibration Range & Instrument Uncertainty \\
\hline Ambient temperature & Resistance Temperature Detector & $-40-60{ }^{\circ} \mathrm{C}$ & $\pm 0.6^{\circ} \mathrm{C}$ \\
Fluid temperature & RTD & $0-200{ }^{\circ} \mathrm{C}$ & $\pm 2.2{ }^{\circ} \mathrm{C}$ \\
Mass flow & Thermocouple, Type $\mathrm{K}$ & $0-2.7 \mathrm{~kg} / \mathrm{s}$ & $\pm 0.1-0.2 \%$ \\
Global solar radiation & Coriolis flow and density meters & $0-2000 \mathrm{~W} / \mathrm{m}^{2}$ & $\pm 1 \%$ \\
Electrical consumption & Three-phase multifunction energy & $0-999,999.99 \mathrm{kWh}$ & $\pm 1 \%$ \\
\hline
\end{tabular}

The installation had two operational modes, namely, the building cooling and heating modes. During the cooling period in summer, the valves V1-V6 and V9-V18 were open and V7 and V8 were closed. The controlling system was achieved through the following main cycles:

\section{(1) The solar loop}

The pump, P1, was switched on when the difference between the outlet temperature of the collector field and the upper layer temperature of the hot water storage tank $T_{3}-T_{4} \geq 4{ }^{\circ} \mathrm{C}$; the pump, $\mathrm{P} 1$, was switched off when the temperature difference $T_{3}-T_{4}<2{ }^{\circ} \mathrm{C}$.

\section{(2) The cooling loop}

The pump, P2, was switched on when the upper layer temperature of the hot water storage tank $T_{4} \geq 80^{\circ} \mathrm{CAND}$ the fan coils were turned on; the pump, $\mathrm{P} 2$, was switched off when $T_{4}<70{ }^{\circ} \mathrm{COR}$ the fan coils were shut down. 


\section{(3) The heat pump loop}

The heat pumps and pump P6 were switched on when the lower layer temperature of the buffer $\operatorname{tank} T_{15}>18^{\circ} \mathrm{C}$ AND the fan coils were turned on; the heat pumps and pump P6 were switched off when $T_{15} \leq 15^{\circ} \mathrm{C}$ OR the fan coils were shut down.

During the heating period in winter, the valves V1, V2, V7-V10, and V13-V18 were open and V3-V6, V11, and V12 were closed. The controlling system was achieved through the following main cycles:

\section{(1) The solar loop}

The pump, P1, was switched on when the difference between the outlet temperature of the collector field and the upper layer temperature of the hot water storage tank $T_{3}-T_{4} \geq 4{ }^{\circ} \mathrm{C}$; the pump, $\mathrm{P} 1$, was switched off when the temperature difference $T_{3}-T_{4}<2{ }^{\circ} \mathrm{C}$.

\section{(2) The heating loop}

The pump, P2, was switched on when the lower layer temperature of the buffer tank $T_{15}<55{ }^{\circ} \mathrm{C}$ AND the difference between the upper layer temperature of the hot water storage tank and the lower layer temperature of the buffer tank $T_{4}-T_{15} \geq 2{ }^{\circ} \mathrm{C}$; the pump, P2, was switched on when the lower layer temperature of the buffer tank $T_{15} \geq 60{ }^{\circ} \mathrm{C}$ OR $T_{4} \leq T_{15}$.

\section{(3) The heat pump loop}

The heat pumps and pump P6 were switched on when the lower layer temperature of the buffer tank $T_{15}<45^{\circ} \mathrm{C}$ AND the fan coils were turned on; the heat pumps and pump P6 were switched off when $T_{15} \geq 50{ }^{\circ} \mathrm{C}$ OR the fan coils were shut down.

\section{Operational Results and Performance Evaluation}

The solar cooling system was installed in December 2017 and has been operating since January 2018. The monthly operational results and performance evaluation as well as those on a typical summer day, namely, 23 July 2018, are presented below.

\subsection{Building Cooling and Heating Energy Demand and Room Temperature}

The room cooling and heating temperatures were set to $22^{\circ} \mathrm{C}$ and $18{ }^{\circ} \mathrm{C}$, respectively, according to the Chinese standards GB 50189-2005 "Design standard for energy efficiency of public buildings" and JGJ 134-2010 "Design standard for energy efficiency of residential buildings in hot-summer and cold-winter zone." Figure 8 shows the monthly average outdoor temperature and building cooling and heating energy demand in 2018. The annual cooling and heating energy demands were $48,418 \mathrm{kWh}$ and $24,288 \mathrm{kWh}$, respectively. The highest cooling demand occurred in July and August, which corresponded to the hottest months in 2018, while the monthly heating energy demands were similar from December to March. There was neither cooling nor heating demand in November and April.

Figure 9 shows the hourly building cooling load and average room temperature on 23 July 2018. The daily cooling energy demand was $435 \mathrm{kWh}$. The room temperature decreased to $21.4^{\circ} \mathrm{C}$ as the solar cooling system started to work at 8:00 in the morning and kept in the range of $21.0-22.0^{\circ} \mathrm{C}$ for $10 \mathrm{~h}$. The room temperature increased rapidly to $27.0^{\circ} \mathrm{C}$ after the system stopped working at 18:00. 


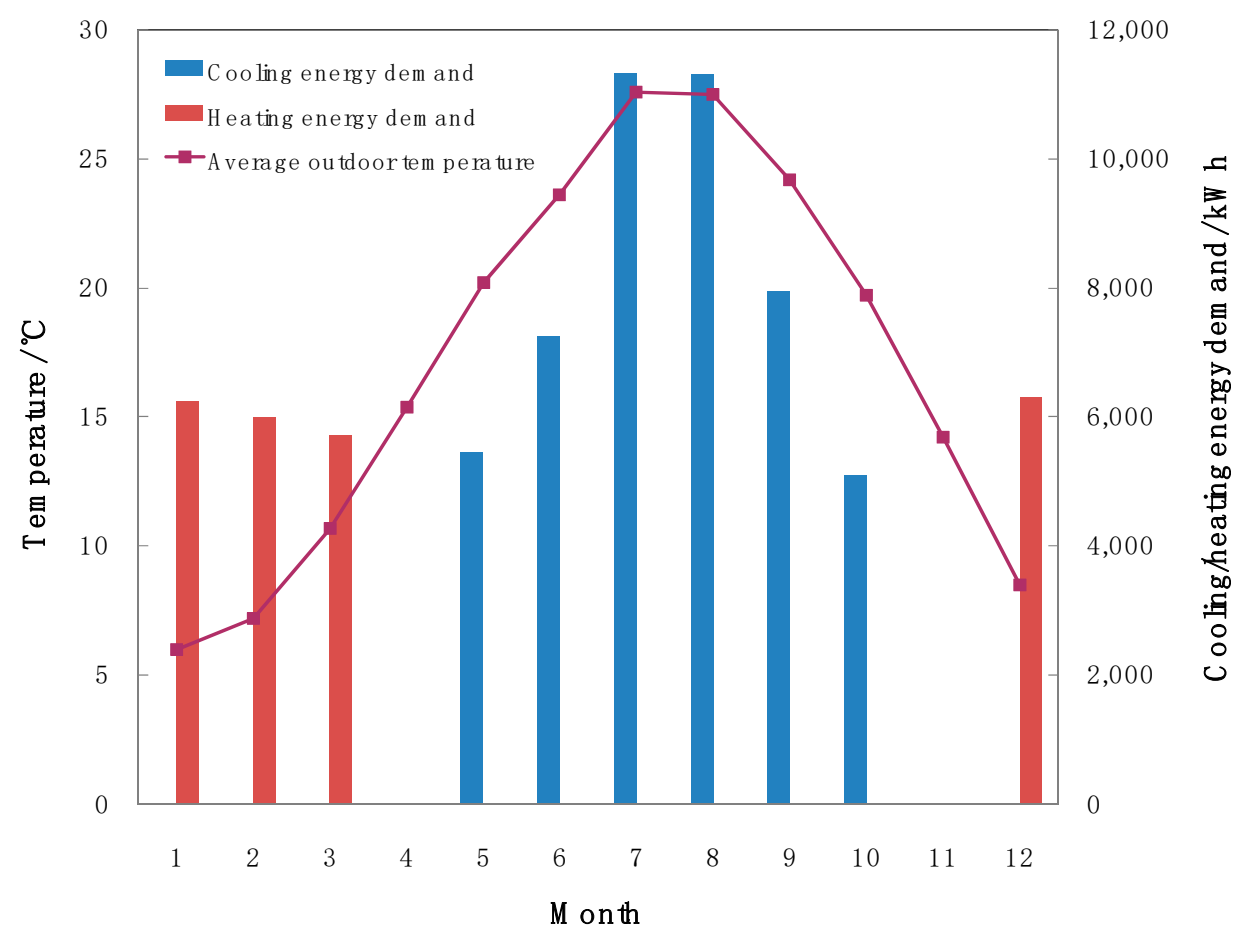

Figure 8. The monthly average outdoor temperature and building cooling and heating energy demand in 2018.
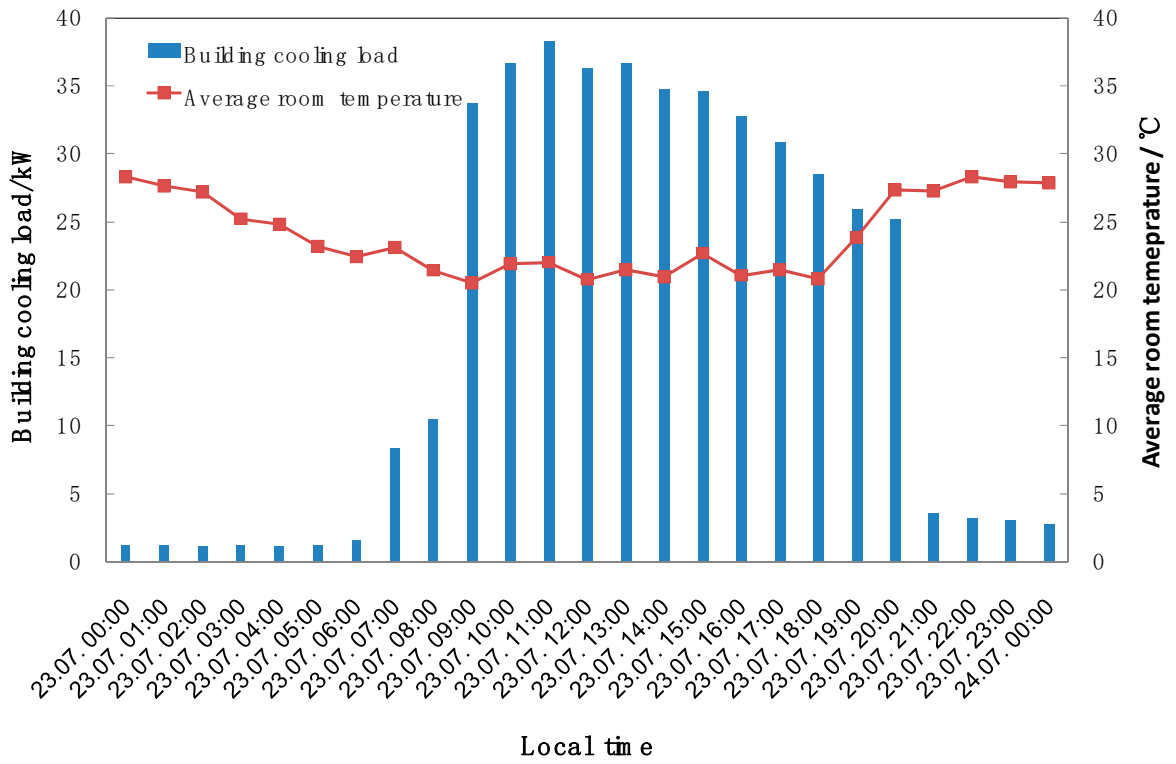

Figure 9. The hourly building cooling load and average room temperature on 23 July 2018.

\subsection{Solar Collector Field}

The collector efficiency $\eta$ is given by Equation (1):

$$
\eta=\frac{Q_{s c}}{Q_{\text {solar }}}=\frac{F_{1} \cdot c_{p, w} \cdot\left(T_{3}-T_{6}\right)}{I_{\text {solar }} \cdot A_{\text {col }}}
$$

where $Q_{\text {solar }}$ and $Q_{\text {sc }}$ represent the total solar energy available and solar energy collected; $I_{\text {solar }}$ is the solar irradiation; $A_{\text {solar }}$ is the aperture area of the solar collectors; $F_{1}$ is the inlet mass flow rate of the collector filed; $c_{\mathrm{p}, \mathrm{w}}$ is the specific heat of water; $T_{3}$ and $T_{6}$ are the outlet and inlet temperatures of the 
solar collection loop, respectively; and $\eta$ is the collector efficiency, with an uncertainty of $3.3 \%$ due to the measurement errors.

Figure 10 presents the monthly solar irradiation onto the collector area and the collector field yield. The solar irradiation onto the collector area from May to October was $94,878 \mathrm{kWh}$ and the collector field yield was $41,849 \mathrm{kWh}$ during the summer cooling time. The annual average collector efficiency for building cooling was $44 \%$, with a maximum of $47 \%$ in August. On the other hand, the solar irradiation onto the collector area from December to March was 42,709 $\mathrm{kWh}$ and the collector field yield was 18,221 kWh during the winter heating time. The annual average collector efficiency for building heating was $42 \%$.

Figure 11 shows the hourly solar irradiation onto the collector area and the collector field yield on 23 July 2018. The daily solar irradiation and collector field yield were $627.7 \mathrm{kWh}$ and $308.5 \mathrm{kWh}$, respectively. The daily average collector efficiency was $49 \%$.

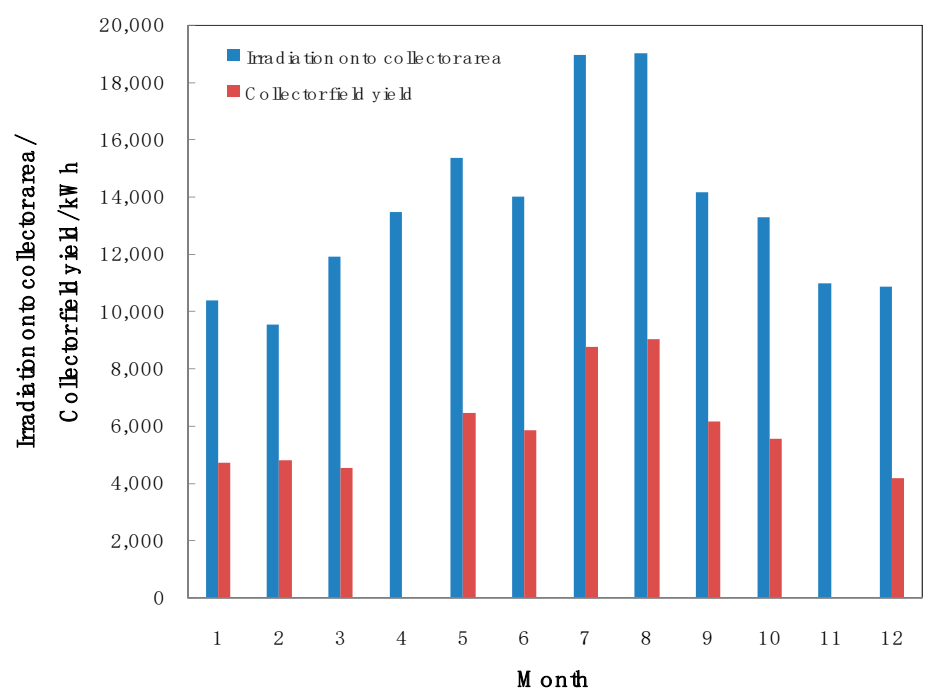

Figure 10. The monthly solar irradiation onto the collector area and the collector filed yield in 2018.

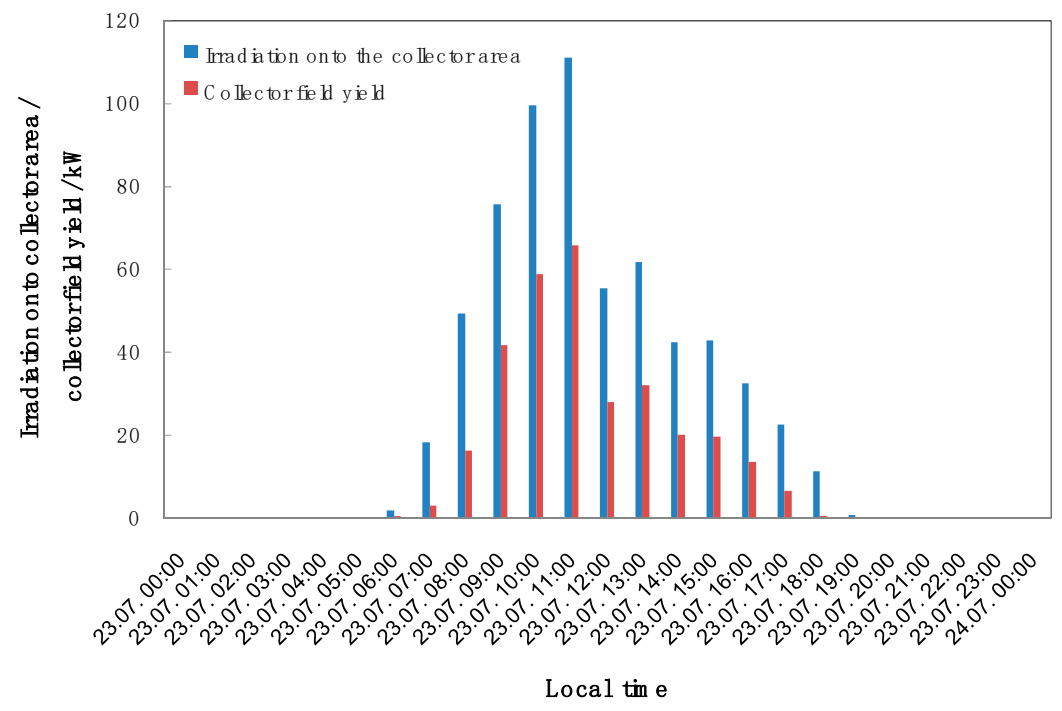

Figure 11. The hourly solar irradiation onto the collector area and the collector filed yield on 23 July 2018. 


\subsection{Absorption Chiller}

The coefficient of performance of the absorption chiller $C O P_{\text {chiller }}$ is defined as the ratio of cooling energy yield and heat supplied by the generator. It is determined on the basis of the Equation (2):

$$
\operatorname{COP}_{\text {chiller }}=\frac{Q_{c}}{Q_{s c}}=\frac{F_{3} \cdot c_{p, w} \cdot\left(T_{11}-T_{10}\right)}{F_{1} \cdot c_{p, w} \cdot\left(T_{3}-T_{6}\right)}
$$

where $Q_{\text {solar }}, Q_{\mathrm{sc}}$ and $Q_{\mathrm{c}}$ represent the total solar energy available, solar energy collected, and cooling energy generated by the chiller driven by solar; $I_{\text {solar }}$ is the solar irradiation; $A_{\text {solar }}$ is the aperture area of the solar collectors; $F_{1}$ and $F_{3}$ are the mass flow rate of the hot water of the absorption chiller and that of the chilled water, respectively; $c_{\mathrm{p}, \mathrm{w}}$ is the specific heat of water; $T_{3}$ and $T_{6}$ are the outlet and inlet temperatures of the solar collection loop, respectively; $T_{10}$ and $T_{11}$ are the chilled water outlet and inlet temperatures of the absorption chiller, respectively; $C O P_{\text {chiller }}$ is the coefficient of performance of the absorption chiller, with an uncertainty of $3.2 \%$ due to the measurement errors.

Figure 12 shows the monthly cooling energy yield of the absorption chiller and heat supplied by the solar collector field in 2018. The annual cooling energy yield and the heat supplied were $27,399 \mathrm{kWh}$ and $37,318 \mathrm{kWh}$ respectively. The monthly average $C O P_{\text {chiller }}$ ranged between 0.68 and 0.76 . The yearly average $C O P_{\text {chiller }}$ was 0.73 .

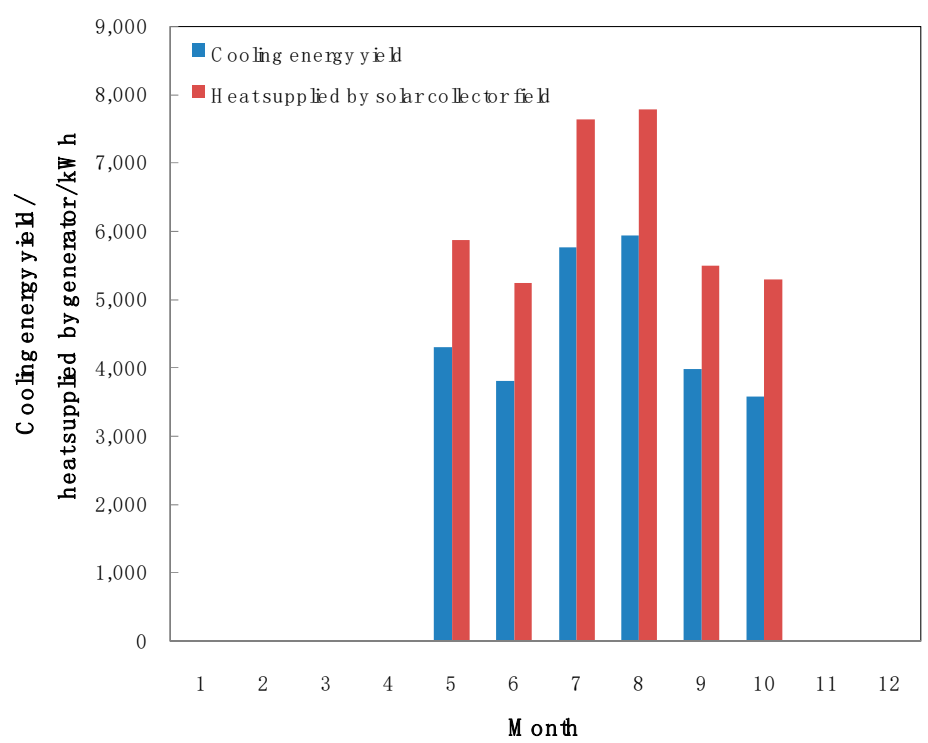

Figure 12. The monthly cooling energy yield of the absorption chiller and heat supplied by the solar collector field in 2018.

Figure 13 presents the hourly cooling energy yield of the absorption chiller and heat supplied by generator on 23 July 2018. The absorption chiller was able to produce chilled water for $6 \mathrm{~h}$ from 10:00 to 16:00. The daily cooling energy yield of the absorption chiller and the heat supplied by the solar collector field were $207.1 \mathrm{kWh}$ and $270.5 \mathrm{kWh}$ respectively. The average coefficient of performance $C O P_{\text {chiller }}$ was 0.76 , with maximums of 0.78 at 13:00 and 14:00 when the inlet hot water reached its highest temperature. It was found that the $C O P_{\text {chiller }}$ increased with the rising hot water inlet temperature. 


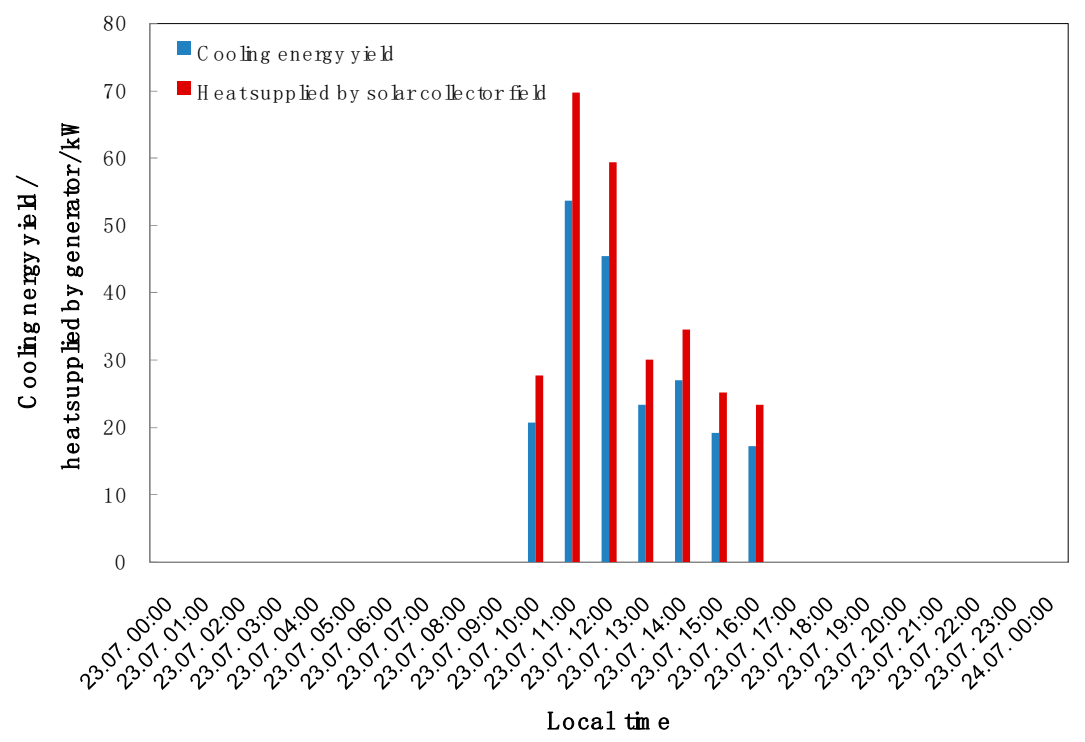

Figure 13. The hourly cooling energy yield of the absorption chiller and heat supplied by generator on 23 July 2018.

Figure 14 presents the hourly hot water, chilled water, and cooling water inlet and outlet temperatures on 23 July 2018. The hot water inlet temperature from the solar collector field reached $106.6^{\circ} \mathrm{C}$ at 12:00, after $2 \mathrm{~h}$ of operation and it remained constant for about $4 \mathrm{~h}$ before decreasing. The chilled water outlet temperature decreased until reaching a minimum value of $10{ }^{\circ} \mathrm{C}$ at 12:00. It remained constant for about $4 \mathrm{~h}$ and then started increasing. Similarly, the cooling water outlet temperature increased until reaching a maximal value of $35^{\circ} \mathrm{C}$ at 12:00. It remained constant for about $4 \mathrm{~h}$, and then started decreasing.

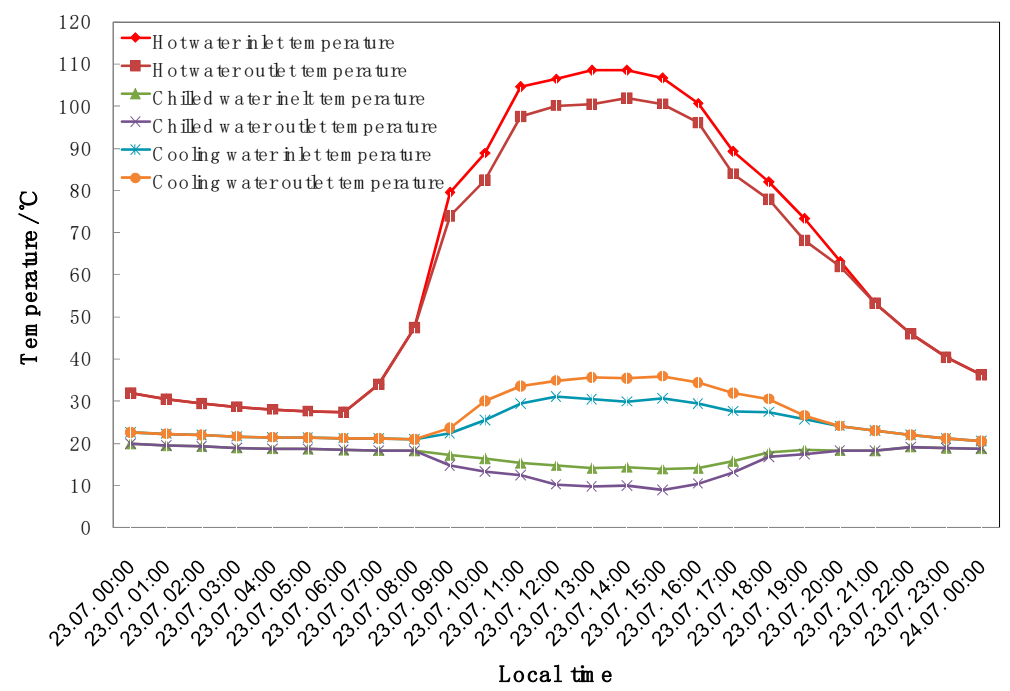

Figure 14. The hourly hot water, chilled water, and cooling water inlet and outlet temperatures on 23 July 2018.

\subsection{Heat Pumps}

The coefficient of performance of the heat pumps $C O P_{\mathrm{hp}}$ is defined as the ratio of cooling/heating energy yield and electrical consumption. It is determined on the basis of the Equations (3) and (4):

$$
\operatorname{COP}_{h p, c}=\frac{Q_{t}-Q_{c}}{E_{1}}=\frac{F_{4} \cdot c_{p, w} \cdot\left(T_{17}-T_{16}\right)-F_{3} \cdot c_{p, w} \cdot\left(T_{11}-T_{10}\right)}{E_{1}}
$$




$$
\operatorname{COP}_{h p, h}=\frac{Q_{t}-Q_{h}}{E_{1}}=\frac{F_{4} \cdot c_{p, w} \cdot\left(T_{17}-T_{16}\right)-F_{2} \cdot c_{p, w} \cdot\left(T_{4}-T_{5}\right)}{E_{1}} .
$$

The solar fraction $S F_{\mathrm{n}}$ is defined as the ratio of the generated cooling or heating by solar to the total generated cooling or heating energy by solar and the heat pumps which corresponds to the total cooling or heating energy used by the fan coils. It can be calculated with the Equations (5) and (6):

$$
\begin{aligned}
& S F_{n, c}=\frac{Q_{c}}{Q_{t}}=\frac{F_{3} \cdot c_{p, w} \cdot\left(T_{11}-T_{10}\right)}{F_{4} \cdot c_{p, w} \cdot\left(T_{17}-T_{16}\right)}, \\
& S F_{n, h}=\frac{Q_{h}}{Q_{t}}=\frac{F_{2} \cdot c_{p, w} \cdot\left(T_{4}-T_{5}\right)}{F_{4} \cdot c_{p, w} \cdot\left(T_{17}-T_{16}\right)},
\end{aligned}
$$

where $Q_{\mathrm{t}}, Q_{\mathrm{c}}$, and $Q_{\mathrm{h}}$ are the total cooling or heating energy used, cooling energy generated by the chiller driven by solar and heating energy generated by solar, respectively; $F_{2}, F_{3}$, and $F_{4}$ are the hot water inlet flow rate of the absorption chiller, chilled water inlet flow rate of the absorption chiller and inlet flow rate of the fan coils, respectively; $c_{\mathrm{p}, \mathrm{w}}$ is the specific heat of water; $T_{4}$ and $T_{5}$ are the upper layer temperature and lower layer temperature of the hot water storage tank, respectively; $T_{10}$ and $T_{11}$ are the chilled water outlet and inlet temperatures of the absorption chiller, respectively; $T_{16}$ and $T_{17}$ are the inlet temperature and outlet temperature of the fan coils, respectively; $E_{1}$ is the electrical consumption of the heat pumps; $C O P_{\mathrm{hp}, \mathrm{c}}$ and $C O P_{\mathrm{hp}, \mathrm{h}}$ are the coefficient of performance of the heat pumps during the summer cooling time and that during the winter heating time, respectively, with an uncertainty of $3.5 \%$ due to the measurement errors; $S F_{n, c}$ and $S F_{n, h}$ are the solar fraction for building cooling and heating, respectively, with an uncertainty of $3.2 \%$ due to the measurement errors.

Figure 15 shows the monthly cooling/heating energy supplied, the electricity consumption, and the coefficient of performance of the heat pumps $C O P_{\mathrm{hp}}$ in 2018. The heat pumps produced a total of 21,019 kWh cooling energy and $9104 \mathrm{kWh}$ heating energy in 2018, corresponding to the electrical consumption of $7439 \mathrm{kWh}$ for cooling and $2851 \mathrm{kWh}$ for heating, respectively. The average coefficient of performance for cooling $C O P_{\mathrm{hp}, \mathrm{c}}$ was 2.83, with minimums of 2.74 and 2.75 in July and August, respectively. The average coefficient of performance for heating $C O P_{\mathrm{hp}, \mathrm{h}}$ was 3.20 .

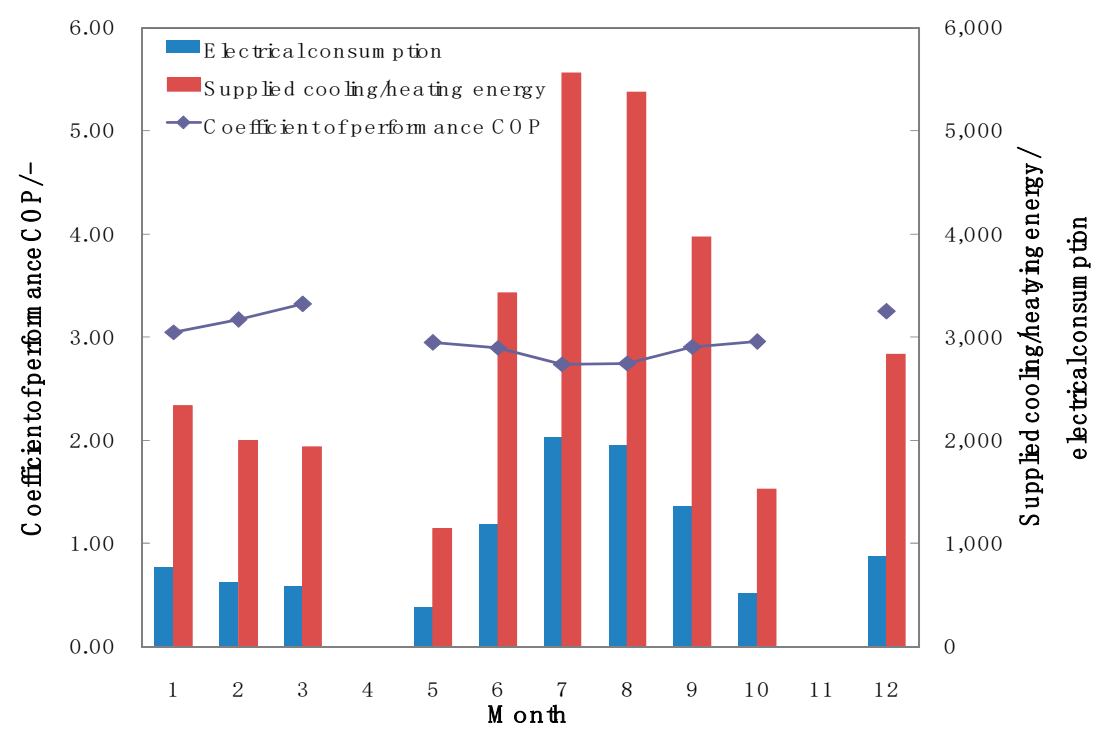

Figure 15. The monthly supplied cooling/heating energy, the electricity consumption, and the coefficient of performance of the heat pumps $C O P_{\mathrm{hp}}$ in 2018.

In order to determine the influence of the heat pumps on the system performance, the heat pumps were switched off on 25, 27, and 28 July 2018 and the system performance was analyzed. As shown in Figure 16, the energy yield and the solar fraction distinctly decreased without the heat pumps as the 
auxiliary system. The daily global irradiation onto the collector area was $661.6 \mathrm{kWh}$ on $28 \mathrm{July}$, which was similar to that of $627.7 \mathrm{kWh}$ on 23 July. However, the collector field yield and the cooling energy yield were $183.9 \mathrm{kWh}$ and $133.7 \mathrm{kWh}$, respectively, which were only $60 \%$ and $50 \%$ of those values on 23 July when incorporated with the heat pumps.

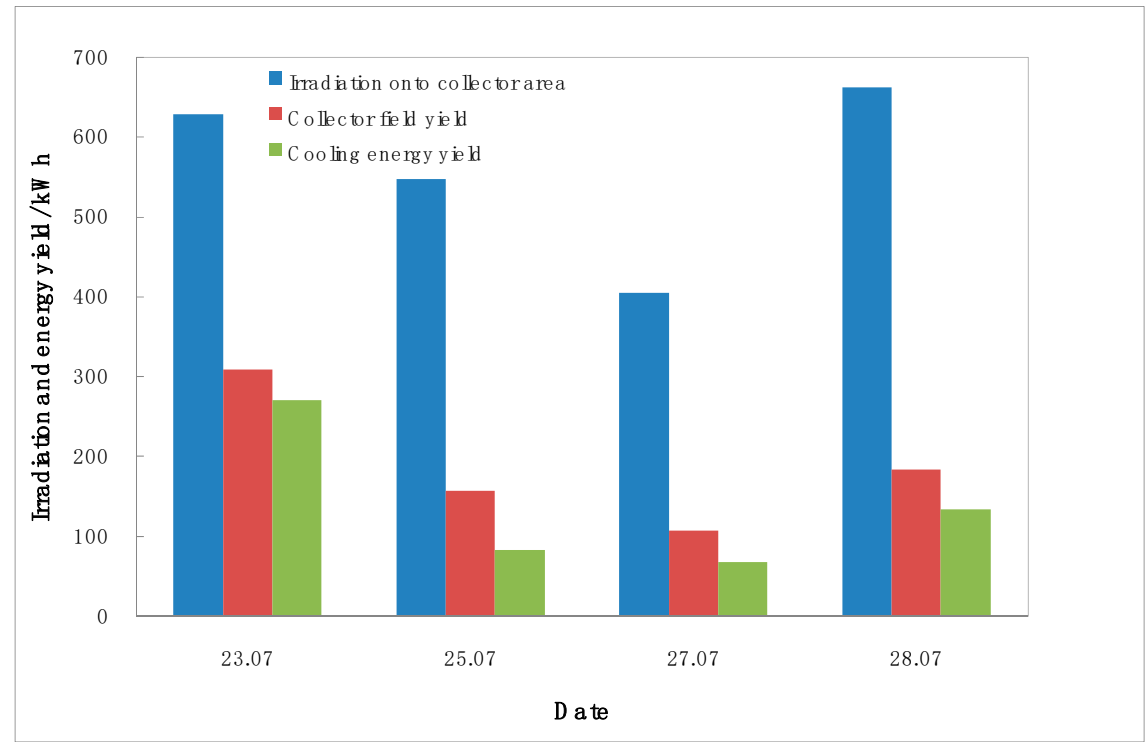

Figure 16. The irradiation onto the collector area, the collector field yield, and the cooling energy yield on $23,25,27$, and 28 July; the heat pumps were switched off on 25, 27, and 28 July2018.

\subsection{Electricity Savings and Emission Reduction}

Figure 17 shows the monthly solar fraction $S F_{\mathrm{n}}$ and electricity savings in 2018 . The annual mean solar fractions for cooling and heating were $56.6 \%$ and $62.5 \%$, respectively. This means that $43.4 \%$ of the annual building cooling demand and $37.5 \%$ of the annual building heating demand were covered by the heat pumps.

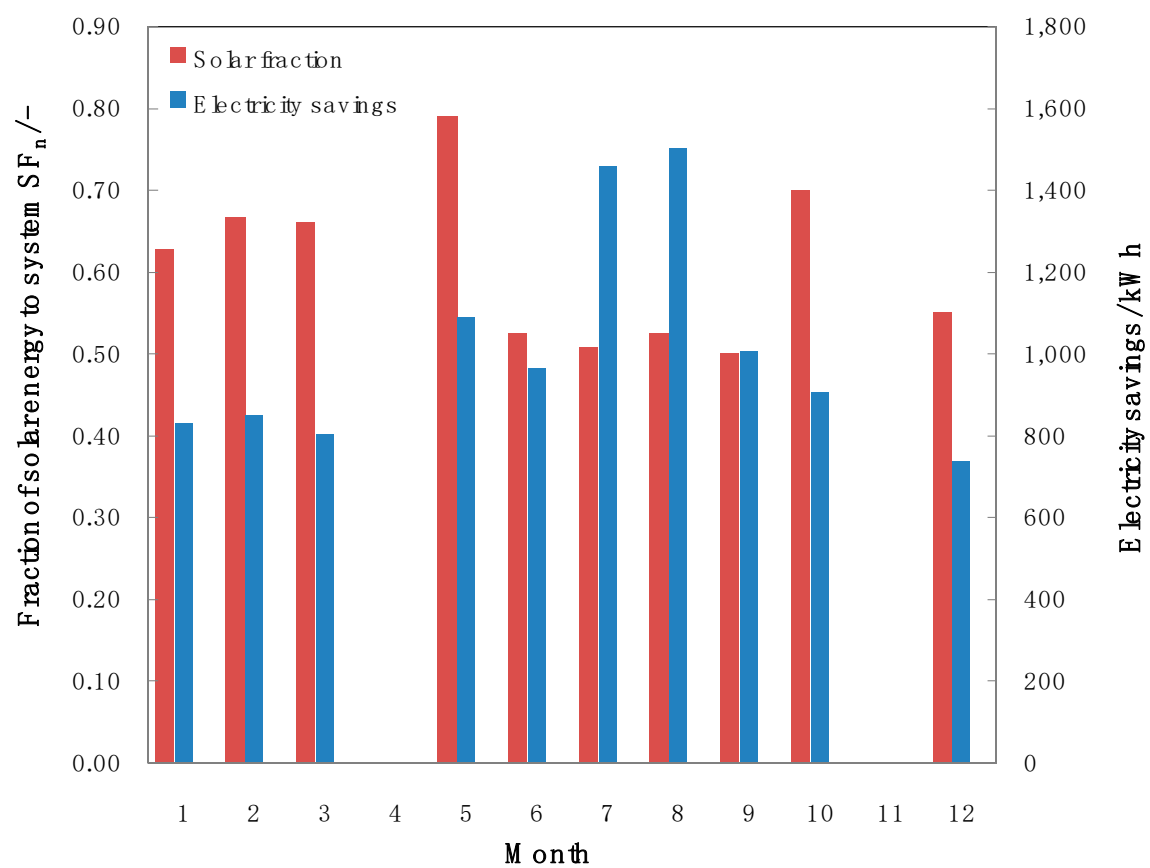

Figure 17. The monthly solar fraction $S F_{\mathrm{n}}$ and electricity savings in 2018. 
One of the essential purposes of the solar cooling and heating systems is to reduce the use of non-solar energy sources such as electricity or fossil fuel burning, which also results in a reduction of $\mathrm{CO}_{2}$ emissions [6]. There are $536 \mathrm{~g}$ of $\mathrm{CO}_{2}$ emitted into the atmosphere for each $\mathrm{kWh}$ of electricity produced. Thus, the conversion factor to calculate the quantities of $\mathrm{CO}_{2}$ emitted is $\mathrm{f}_{\mathrm{c}}=0.54 \mathrm{~kg} / \mathrm{kWh}$. Assuming that all building cooling and heating demands were covered by the two air-source heat pumps with the mean cooling $C O P_{\mathrm{hp}, \mathrm{c}}$ of 2.83 and mean heating $C O P_{\mathrm{hp}, \mathrm{h}}$ of 3.20 , the annual total electricity consumption was $24,699 \mathrm{kWh}$. The yearly electricity saving was $10,158.6 \mathrm{kWh}$ when combined with the solar cooling and heating system, which accounted for $41.1 \%$ of the total electricity consumption for the building cooling and heating and corresponds to $5445 \mathrm{~kg}$ of $\mathrm{CO}_{2}$ emissions prevented from being released into the atmosphere.

\section{Discussion and Conclusions}

An absorption solar cooling and heating system assisted by two air-source heat pumps located in Ningbo City, China was studied in this paper. The system started operating in 2018 and the operational results were evaluated. Based on this study, the main conclusions are as follows:

- The solar collector field was comprised of 40 all-glass evacuated tube modules with a total aperture area of $120 \mathrm{~m}^{2}$. The annual average collector efficiency was $44 \%$ for building cooling and $42 \%$ for building heating.

- The single-stage and LiBr-water based absorption chiller had a cooling capacity of $35 \mathrm{~kW}$. The monthly average coefficient of performance $C O P_{\text {chiller }}$ ranged between 0.68 and 0.76 in 2018. The $C O P_{\text {chiller }}$ increased with the rising hot water inlet temperature.

- Two air-source heat pumps each with a rated cooling capacity of $23.8 \mathrm{~kW}$ and heating capacity of $33 \mathrm{~kW}$ were used as the auxiliary system for the solar cooling and heating installation. The average coefficient of performance $C O P_{\mathrm{hp}, \mathrm{c}}$ was 2.83 in 2018, with minimums of 2.74 and 2.75 in July and August, respectively. The average coefficient of performance for heating $C O P_{\mathrm{hp}, \mathrm{h}}$ was 3.20.

- The energy yields distinctly decreased without the heat pumps as the auxiliary system. In comparison with the case combined with the heat pumps under similar irradiation conditions, the collector field yield and cooling energy yield decreased by more than $40 \%$.

- Two kinds of operational modes were conducted, namely, the building cooling and heating modes. The annual mean solar fractions for cooling and heating were $56.6 \%$ and $62.5 \%$, respectively. The yearly electricity saving was $10,158.6 \mathrm{kWh}$ when combined with the solar cooling and heating system, which accounted for $41.1 \%$ of the total electricity consumption for building cooling and heating and corresponds to $5445 \mathrm{~kg}$ of $\mathrm{CO}_{2}$ emissions prevented from being released into the atmosphere.

Author Contributions: Methodology and writing—original draft preparation, L.H.; Project administration, R.Z.; Data curation, U.P.

Funding: This research was funded by a grant from the National Key Technology Support Program of the Twelfth Five-Year of the People's Republic of China, grant number 2013BAJ10B06, project title "The integration and demonstration of construction technology on the ecosystem villages and towns and well-off residences in the southeast coastal area."

Acknowledgments: All support given for this paper is covered by the author contribution and funding sections.

Conflicts of Interest: The authors declare no conflict of interest. 


\section{Nomenclature}

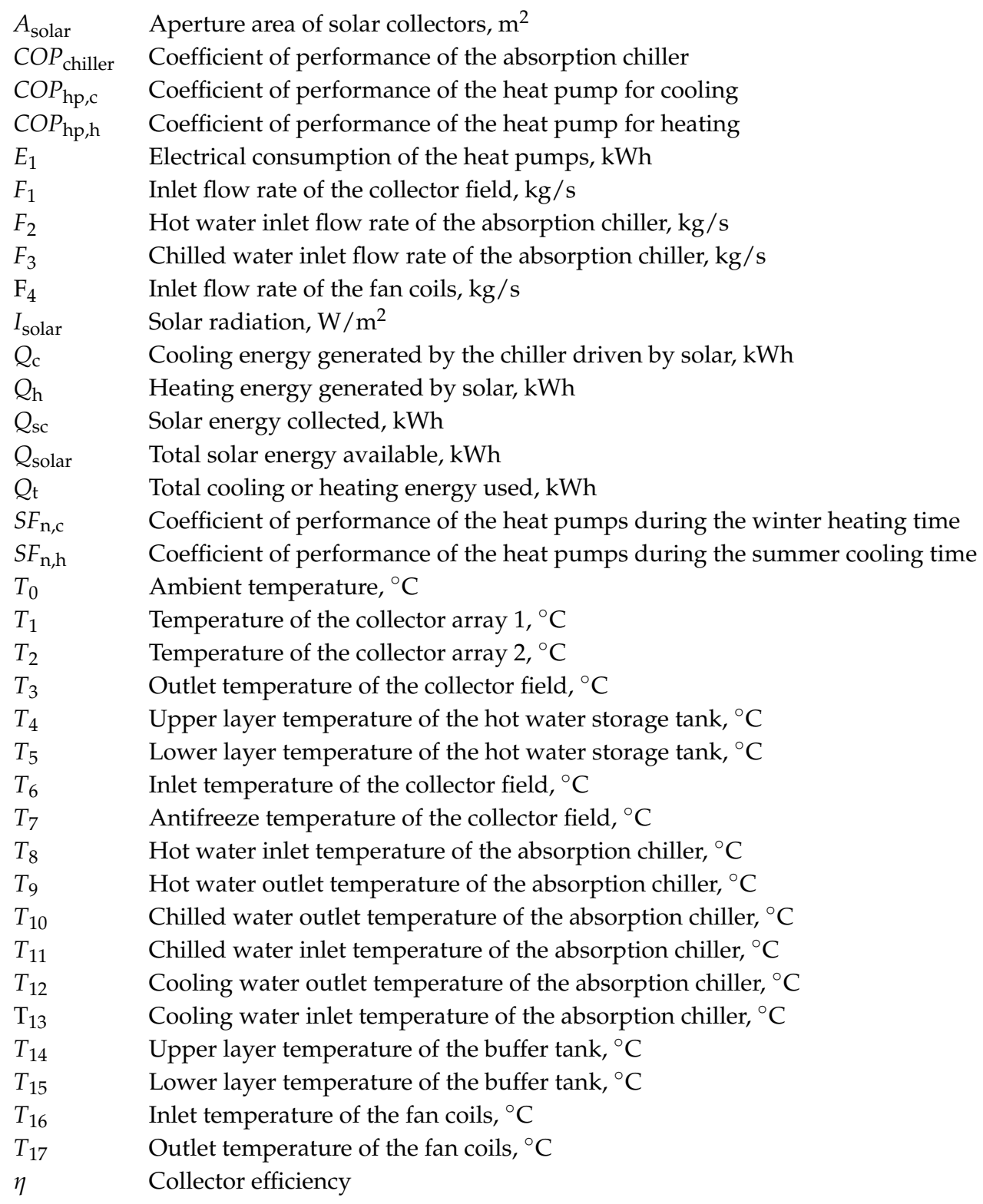

\section{References}

1. Zhao, H.X.; Frédéric, M. A review on the prediction of building energy consumption. Renew. Energ. Rev. 2012, 4, 3586-3592. [CrossRef]

2. Yang, X.M. The energy consumption and savings of public buildings in Shanghai. Master Thesis, Tongji University, Shanghai, China, 2007.

3. Mugnier, D. State of the art for solar thermal or PV cooling and refrigeration. In Proceedings of the Solar Heating \& Cooling Program SHC 2014 Conference, Beijing, China, 15 October 2014.

4. Syed, A.; Izquierdo, M.; Rodriguez, P.; Maidment, G.; Missenden, J.; Lecuona, A.; Tozer, R. A novel experimental investigation of a solar cooling system in Madrid. Int. J. Refrig. 2005, 28, 859-871. [CrossRef]

5. Pongtornkulpanich, A.; Thepa, S.; Amornkitbamrung, M.; Butcher, C. Experience with fully operational solar-driven 10 ton $\mathrm{LiBr} / \mathrm{H}_{2} \mathrm{O}$ single-effect absorption cooling system in Thailand. Renew. Energy 2008, 33, 943-949. [CrossRef]

6. Rosiek, S.; Batlles, F.Z. Integration of the solar thermal energy in the construction: Analysis of the solar-assisted air-conditioning system installed in CIESOL building. Renew. Energy 2009, 34, 1423-1431. [CrossRef] 
7. Bermejo, P.; Pino, F.J.; Rosa, F. Solar absorption cooling plant in Seville. Sol. Energy 2010, 84, $1503-1512$. [CrossRef]

8. Lizarte, R.; Izquerdo, M.; Marcos, J.D.; Palacios, E. An innovative solar-driven directly air-cooled LiBr- $\mathrm{H}_{2} \mathrm{O}$ absorption chiller prototype for residential use. Energy Build. 2012, 47, 1-11. [CrossRef]

9. Balghouthi, M.; Chahbani, M.H.; Guizani, A. Investigation of a solar cooling installation in Tunisia. Appl. Energy 2012, 98, 138-148. [CrossRef]

10. Hang, Y.; Qu, M.; Winston, R.; Jiang, L.; Widyolar, B.; Poiry, H. Experimental based energy performance analysis and life cycle assessment for solar absorption cooling system at University of Californian, Merced. Energy Build. 2014, 82, 746-757. [CrossRef]

11. Marc, O.; Sinama, F.; Praene, J.P.; Lucas, F.; Castaing-Lasvignottes, J. Dynamic modeling and experimental validation elements of a $30 \mathrm{~kW} \mathrm{LiBr} / \mathrm{H}_{2} \mathrm{O}$ single effect absorption chiller for solar application. Appl. Therm. Eng. 2015, 90, 980-993. [CrossRef]

12. Xu, Z.Y.; Wang, R.Z.; Wang, H.B. Experimental evaluation of a variable effect LiBr-water absorption chiller designed for high-efficient solar cooling system. Int. J. Refrig. 2015, 59, 135-143. [CrossRef]

13. Sumathy, K.; Huang, Z.C.; Li, Z.F. Solar absorption cooling with low grade heat source-A strategy of development in South China. Sol. Energy 2002, 72, 155-165. [CrossRef]

14. Li, J.; Bai, N.; Ma, W. Large solar powered air conditioning-heat pump system. Acta Energiae Solaris Sinica 2006, 27, 152-158. (In Chinese)

15. Han, J.; Xie, G.; Feng, L. Demonstration project of Beiyuan solar energy system. In Proceedings of the Moderate and High Temperature Solar Collectors and Solar Heating and Cooling Conference, Shanghai, China, 2006. (In Chinese)

16. Shirazi, A.; Taylor, R.A.; Morrison, G.L.; White, S.D. Solar-powered absorption chillers: A comprehensive and critical review. Energy Convers Manag. 2018, 171, 59-81. [CrossRef]

(C) 2019 by the authors. Licensee MDPI, Basel, Switzerland. This article is an open access article distributed under the terms and conditions of the Creative Commons Attribution (CC BY) license (http://creativecommons.org/licenses/by/4.0/). 